Biogeosciences Discuss., 6, 6579-6599, 2009

www.biogeosciences-discuss.net/6/6579/2009/

(C) Author(s) 2009. This work is distributed under

\title{
Linking the lithogenic, atmospheric, and biogenic cycles of silicate, carbonate, and organic carbon in the ocean
}

S. V. Smith ${ }^{1}$ and J.-P. Gattuso ${ }^{2,3}$

${ }^{1}$ Centro de Investigación Científica y de Educación Superior de Ensenada (CICESE) Ensenada, Baja California, Mexico

${ }^{2}$ INSU-CNRS, Laboratoire d'Océanographie de Villefranche, B.P. 28, 06234

Villefranche-sur-mer Cedex, France

${ }^{3}$ UPMC University of Paris 06, Observatoire Océanologique de Villefranche-sur-Mer, 06230

Villefranche-sur-mer, France

Received: 21 June 2009 - Accepted: 25 June 2009 - Published: 6 July 2009

Correspondence to: S.V. Smith (svsmith@ cicese.mx)

Published by Copernicus Publications on behalf of the European Geosciences Union.

Lithogenic, atmospheric, and biogenic cycles

S. V. Smith and

J.-P. Gattuso

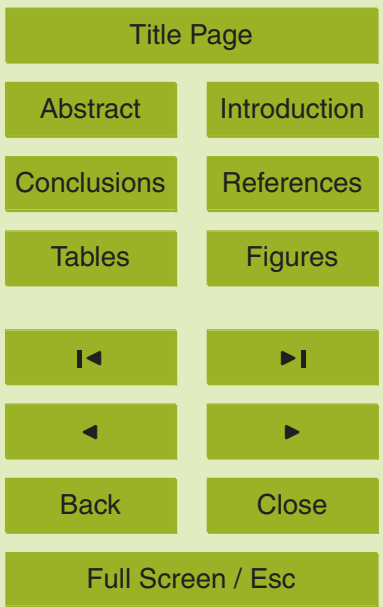

Printer-friendly Version

Interactive Discussion 


\section{Abstract}

Geochemical theory describes long term cycling of atmospheric $\mathrm{CO}_{2}$ between the atmosphere and rocks at the Earth surface in terms of rock weathering and precipitation of sedimentary minerals. Chemical weathering of silicate rocks takes up atmospheric $\mathrm{CO}_{2}$, releases cations and $\mathrm{HCO}_{3}^{-}$to water, and precipitates $\mathrm{SiO}_{2}$, while $\mathrm{CaCO}_{3}$ precipitation consumes $\mathrm{Ca}^{2+}$ and $\mathrm{HCO}_{3}^{-}$and releases one mole of $\mathrm{CO}_{2}$ to the atmosphere for each mole of $\mathrm{CaCO}_{3}$ precipitated. At steady state, according to this theory, the $\mathrm{CO}_{2}$ uptake and release should equal one another. In contradiction to this theory, carbonate precipitation in the present surface ocean releases only about $0.6 \mathrm{~mol}$ of $\mathrm{CO}_{2}$ per 10 mole of carbonate precipitated. This is a result of the buffer effect described by $\Psi$, the molar ratio of net $\mathrm{CO}_{2}$ gas evasion to net $\mathrm{CaCO}_{3}$ precipitation from seawater in $p \mathrm{CO}_{2}$ equilibrium with the atmosphere. This asymmetry in $\mathrm{CO}_{2}$ flux between weathering and precipitation would quickly exhaust atmospheric $\mathrm{CO}_{2}$, posing a conundrum in the classical weathering and precipitation cycle.

While often treated as a constant, $\Psi$ actually varies as a function of salinity, $p \mathrm{CO}_{2}$, and temperature. Introduction of organic $\mathrm{C}$ reactions into the weathering-precipitation couplet largely reconciles the relationship. $\psi$ in the North Pacific Ocean central gyre rises from 0.6 to 0.9 , as a consequence of organic matter oxidation in the water column. $\psi$ records the combined effect of $\mathrm{CaCO}_{3}$ and organic reactions and storage of dissolved inorganic carbon in the ocean, as well as $\mathrm{CO}_{2}$ gas exchange between the ocean and atmosphere. Further, in the absence of $\mathrm{CaCO}_{3}$ reactions, $\Psi$ would rise to 1.0. Similarly, increasing atmospheric $p \mathrm{CO}_{2}$ over time, which leads to ocean acidification, alters the relationship between organic and inorganic $C$ reactions and carbon storage in the ocean. Thus, the carbon reactions and $\psi$ can cause large variations in
BGD

$6,6579-6599,2009$

\section{Lithogenic, atmospheric, and biogenic cycles}

S. V. Smith and J.-P. Gattuso

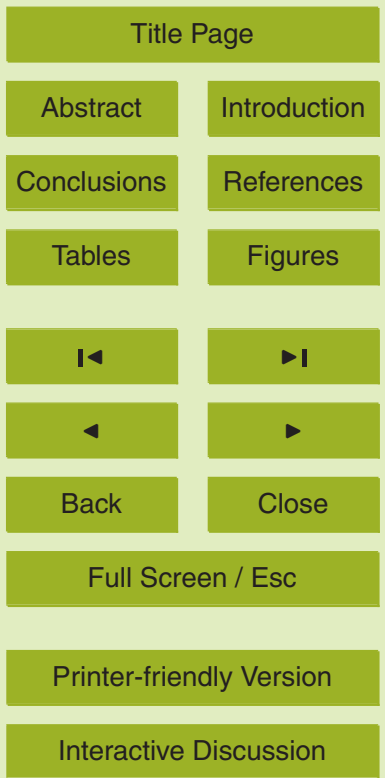




\section{Introduction}

Weathering and precipitation, among others processes, work in concert and coupled with other cycles to control the composition of the atmosphere and oceans (Arvidson et al. 2006). In particular, weathering and precipitation of silicate and carbonate miner5 als have long been recognized as key processes in the long-term global carbon cycle. Equations describing these reactions were apparently first written by Urey (1952), but Berner and Maasch (1996) have traced the concept to the much earlier work of Ebelmen (1845). The following two equations (from Urey, 1952) can be used to represent silicate mineral weathering and carbonate mineral precipitation, respectively:

$$
\begin{aligned}
& \mathrm{CaSiO}_{3}+2 \mathrm{CO}_{2}+\mathrm{H}_{2} \mathrm{O} \rightarrow \mathrm{Ca}^{2+}+2 \mathrm{HCO}_{3}^{-}+\mathrm{SiO}_{2} \downarrow \\
& \mathrm{Ca}^{2+}+2 \mathrm{HCO}_{3}^{-} \rightarrow \mathrm{CaCO}_{3} \downarrow+\mathrm{CO}_{2} \uparrow+\mathrm{H}_{2} \mathrm{O}
\end{aligned}
$$

The two equations taken together provide the geochemical explanation for the counterintuitive fact that $\mathrm{CaCO}_{3}$ precipitation releases $\mathrm{CO}_{2}$ to the atmosphere, rather than taking up atmospheric $\mathrm{CO}_{2}$ (Gattuso et al., 1999a). Carbon incorporated into $\mathrm{CaCO}_{3}$ 15 during precipitation is directly derived from $\mathrm{HCO}_{3}^{-}$ions, not from atmospheric $\mathrm{CO}_{2}$. That $\mathrm{HCO}_{3}^{-}$is, in turn, derived from atmospheric $\mathrm{CO}_{2}$ via the chemical weathering of rocks. These equations can be combined to describe the net reaction of igneous and metamorphic silicate minerals and $\mathrm{CO}_{2}$ from the Earth interior to form sedimentary carbonate (e.g., $\left.\mathrm{CaCO}_{3}\right)$ and silica $\left(\mathrm{SiO}_{2}\right)$ at the Earth surface:$$
\mathrm{CaSiO}_{3}+\mathrm{CO}_{2} \leftrightarrow \mathrm{CaCO}_{3} \downarrow+\mathrm{SiO}_{2} \downarrow
$$

While both sedimentary $\mathrm{CaCO}_{3}$ and $\mathrm{SiO}_{2}$ can form by inorganic chemical precipitation, their precipitation in the contemporary ocean is driven overwhelmingly by biotic processes (biomineralization).

At steady state according to Eq. (3), there is no net $\mathrm{CO}_{2}$ flux between air and water.

Deviations from steady state would cause changes in the carbon content of all carbon reservoirs (rocks, water, air, organic matter). Of immediate relevance to this paper, the

\section{BGD}

$6,6579-6599,2009$

\section{Lithogenic, atmospheric, and biogenic cycles}

S. V. Smith and J.-P. Gattuso

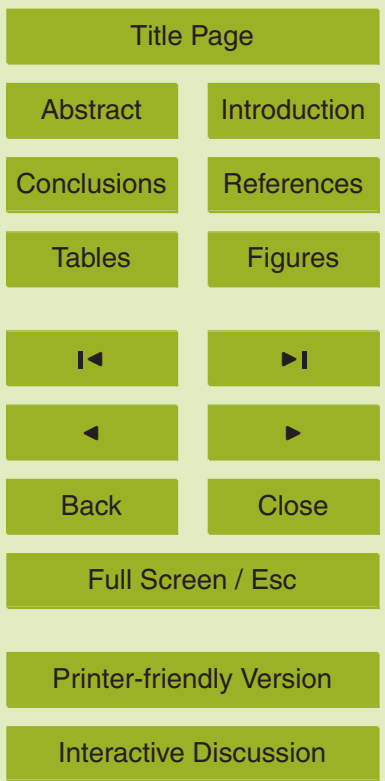


atmosphere (by far, the smallest of these reservoirs) equals about $2 \%$ of the mass of inorganic carbon dissolved in water (primarily the ocean; Berner, 1990; Sigman and Boyle, 2000). Therefore the atmosphere is particularly sensitive to deviations from steady state.

$5 \quad$ Herein, we summarize a problem we have recognized from oceanic ecosystems that we have studied; we use data from a well described oceanic site to explore the problem at an ocean-basin scale; and we develop geochemical scenarios in order to explore and resolve the problem.

\section{Observations and calculations leading to the "carbonate conundrum"}

10 Our field studies and geochemical calculations over some years for two types of calcifying marine ecosystems initially brought our attention to an apparent problem within the Ebelmen-Urey cycle; ongoing consideration of the problem has eventually led us to a plausible resolution. The relevant types of ecosystems we have studied are: (1) coral reefs, which are characterized by very rapid rates of $\mathrm{CaCO}_{3}$ precipitation and 15 organic metabolism; and (2) shallow, confined basins, which typically have low rates of carbonate precipitation and organic metabolism and lack significant terrigenous or marine inputs of materials.

Both types of system receive little other than dissolved inorganic carbon from outside of the systems (much of that via the atmosphere). Both produce organic $\mathrm{C}$ more 20 rapidly than $\mathrm{CaCO}_{3}$. Yet both types of ecosystem have residual products (sediments) dominated by $\mathrm{CaCO}_{3}$, indicating that most organic $\mathrm{C}$ produced in the systems oxidizes there. Both show clear signals of altered water composition with respect to dissolved inorganic carbon, relative to surrounding water, in response to compositional dominance by net internal reactions. These $\mathrm{CaCO}_{3}$ dominated ecosystems provide insight into aspects of the oceanic $\mathrm{CO}_{2}$ system, because of their well-defined biogeochemical signals with respect to $\mathrm{CaCO}_{3}$. Lessons learned in these systems also apply to other calcifying ecosystems and communities (e.g., oceanic plankton).

\section{BGD}

6, 6579-6599, 2009

\section{Lithogenic, atmospheric, and biogenic cycles}

S. V. Smith and J.-P. Gattuso

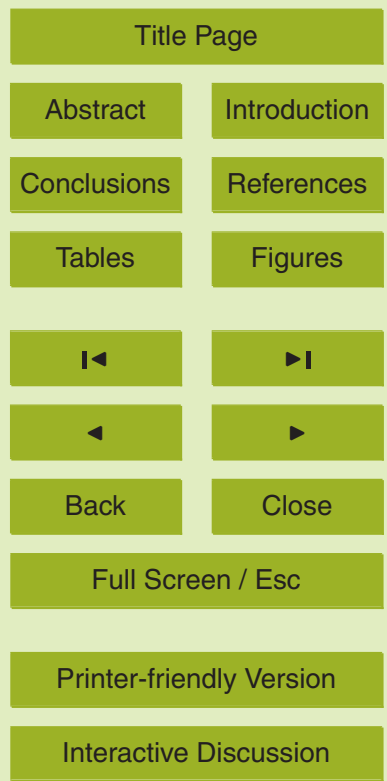


The Ebelmen-Urey reaction for carbonate precipitation and dissolution (Eq. 2) adequately characterizes these processes in freshwater, but analysis of the aqueous $\mathrm{CO}_{2}$ system of ecosystems that we have studied led us to recognize a problem with the quantitative application of Eq. (2) in surface seawater. We found that this equation 5 does not represent the quantitative balance between $\mathrm{CaCO}_{3}$ precipitation and $\mathrm{CO}_{2}$ gas evasion from surface seawater (Smith, 1985; Ware et al., 1991; Frankignoulle et al. 1994).

Total dissolved inorganic carbon $\left(\mathrm{DIC}=\left[\mathrm{CO}_{2}^{*}\right]+\left[\mathrm{HCO}_{3}^{-}\right]+\left[\mathrm{CO}_{3}^{2-}\right]\right)$ is the sum of the various species or inorganic carbon, where $\mathrm{CO}_{2}^{*}=\mathrm{CO}_{2}+\mathrm{H}_{2} \mathrm{CO}_{3}$. The partitioning among 10 these species is controlled by $\mathrm{pH}$ (as well as temperature, salinity and hydrostatic pressure). Un-dissociated $\mathrm{H}_{2} \mathrm{CO}_{3}$ is hydrated $\mathrm{CO}_{2}$, which is in approximate gas equilibrium with atmospheric $\mathrm{CO}_{2}$. For water of any given temperature and salinity, any two variables of the carbonate system can be used to partition the carbonate system into its various components (Park, 1969). The choice of variables is often determined by 15 a consideration of easy or accurate measurements. This choice can also be based on scenario testing, which may be viewed as "conceptual experiments" requiring manipulation of specific variables.

Precipitating $\mathrm{CaCO}_{3}$ according to Eq. (2) would remove two moles of $\mathrm{HCO}_{3}^{-}$and two equivalents of total alkalinity (TA) from water for each mole of $\mathrm{CaCO}_{3}$ precipitated, where TA is the number of moles of hydrogen ion equivalent to the excess of proton acceptors over proton donors (Dickson, 1981), i.e., $2 \mathrm{HCO}_{3}^{-}$in Eq. (2). The quantitative problem with the equation may be illustrated by the following simple scenario. We begin with seawater in $p \mathrm{CO}_{2}$ equilibrium with the atmosphere; the two variables describing the aqueous $\mathrm{CO}_{2}$ system in this case are $\mathrm{TA}$ and $p \mathrm{CO}_{2}$. Precipitate $\mathrm{CaCO}_{3}$ according 25 to Eq. (2) (removing one mol of $\mathrm{HCO}_{3}^{-}$as $\mathrm{CO}_{2}$ gas for each mol of $\mathrm{HCO}_{3}$ removed as $\mathrm{CaCO}_{3}$; this removes two equivalents of TA). Finally, calculate the $p \mathrm{CO}_{2}$ of that water with the prescribed changes in TA and DIC. For seawater, the removal of TA and $\mathrm{HCO}_{3}^{-}$ as described by Eq. (2) would cause $p \mathrm{CO}_{2 \text { (water) }}$ to drop below $p \mathrm{CO}_{2 \text { (air) }}$.

It is well recognized that the physical force that causes $\mathrm{CO}_{2}$ gas evasion from water at

\section{BGD}

$6,6579-6599,2009$

\section{Lithogenic, atmospheric, and biogenic cycles}

S. V. Smith and J.-P. Gattuso

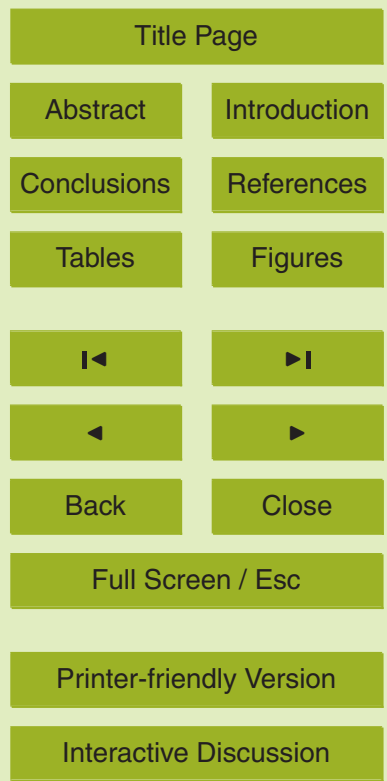


$p \mathrm{CO}_{2}$ equilibrium with the atmosphere is the $\mathrm{CO}_{2}$ partial pressure differential between water and air, so the amount of gas flux predicted by Eq. (2) is physically impossible (Smith, 1985). The sequence of events is as follows. $\mathrm{CaCO}_{3}$ precipitation immediately causes the $p \mathrm{CO}_{2}$ of the water to rise. Over time, some amount of $\mathrm{CO}_{2}$ will escape to 5 the atmosphere, and the $p \mathrm{CO}_{2}$ of the water will return towards atmospheric equilibrium. The maximum amount of $\mathrm{CO}_{2}$ that can evade in response to the precipitation is just sufficient to return $p \mathrm{CO}_{2}$ back to equilibrium.

Ware et al. (1991) pointed out that the problem of gas flux against a pressure differential could be readily circumvented by using a coefficient smaller than 1.0 in Eq. (2) for 10 the ratio of $\mathrm{CO}_{2}$ efflux to $\mathrm{CaCO}_{3}$ precipitation. The coefficient they determined (for tropical surface ocean seawater $\left(T=25^{\circ} \mathrm{C}, S=35, p \mathrm{CO}_{2(\text { water })}=p \mathrm{CO}_{2 \text { (air) }}=350 \mathrm{ppmv}\right)$ was 0.6. Calculations using experimental data available in Wollast et al. (1980) were used to demonstrate that this coefficient is observed in real data. Ware et al. (1991) termed this the "0.6 rule."Frankignoulle et al. (1994) confirmed the calculations of Ware and colleagues; most importantly, they also recognized that this coefficient (which they termed $\psi$ ) is not constant, but varies as a function of temperature, salinity and $p \mathrm{CO}_{2}$.

Equation (2) can be re-cast into a general expression that includes $\psi$ :

$\mathrm{Ca}^{2+}+2 \mathrm{HCO}_{3}^{-} \rightarrow \mathrm{CaCO}_{3} \downarrow+\psi\left(\mathrm{CO}_{2} \uparrow+\mathrm{H}_{2} \mathrm{O}\right)+(1-\psi)\left(\mathrm{HCO}_{3}^{-}+\mathrm{H}^{+}\right)$

This equation demonstrates that the $\mathrm{HCO}_{3}^{-}$that does not escape to the atmosphere 20 as $\mathrm{CO}_{2}$ gas is retained in the water as a result of the buffer capacity of the water. Because freshwater has very low buffer capacity, the $\mathrm{CO}_{2}$ is released rather than retained in the water as $\mathrm{HCO}_{3}^{-}$(i.e., $\psi=1.0$ ), with a concomitant decrease in $\mathrm{pH}$ once the water returns to partial pressure equilibrium. This formulation includes an accounting for the $\mathrm{pH}$ change associated with the reaction.

Frankignoulle (1994) presented the buffer factors by which $\psi$ can be calculated directly. The calculations as performed by Ware et al. (1991), before and after precipitation or dissolution of some hypothetical amount of $\mathrm{CaCO}_{3}$, implicitly invoke these buffer factors.

BGD

$6,6579-6599,2009$

\section{Lithogenic, atmospheric, and biogenic cycles}

S. V. Smith and J.-P. Gattuso

Title Page

Abstract Introduction

Conclusions

Tables References Figures

14

4

Back

Full Screen / Esc

Printer-friendly Version

Interactive Discussion 
The "0.6 rule," or relationship between $\mathrm{CaCO}_{3}$ precipitation and $\mathrm{CO}_{2}$ gas evasion, has come to be generally recognized and treated as approximately constant, without apparent recognition that it poses a conundrum with respect to the Ebelmen-Urey cycle. We term this, the "carbonate conundrum." If the equations of that cycle are ac-

5 cepted as a qualitatively correct representation of the long-term carbon cycle of weathering and precipitation of silicate and carbonate minerals, then replacing Eq. (2) with (4) (that is, with $\psi<1.0$ ) sets up a large asymmetry between the uptake and release of atmospheric $\mathrm{CO}_{2}$ (Eq. 1).

If we assume steady state, more $\mathrm{CO}_{2}$ is apparently removed from the contempo10 rary atmosphere by $\mathrm{CaSiO}_{3}$ weathering than is released by $\mathrm{CaCO}_{3}$ precipitation. The magnitude of this asymmetry is substantial. Application of the " 0.6 rule" to estimated present rates of net $\mathrm{CaCO}_{3}$ burial $\left(\sim 30 \times 10^{12} \mathrm{~mol} \mathrm{yr}^{-1}\right.$; from Milliman and Droxler, 1996) suggests that the asymmetry would be sufficient to exhaust atmospheric $\mathrm{CO}_{2}$ $\left(\sim 60 \times 10^{15} \mathrm{~mol}\right)$ in $<10^{4}$ years. Clearly atmospheric fluctuations of this magnitude do 15 not occur on this time scale. Oceanic processes must have some internal mechanism to allow for substantial fluctuation of internal DIC with relatively little atmospheric exchange.

Despite this obvious problem, let us tentatively continue to accept that the cycle of rock weathering and mineral precipitation is a reasonable representation of a "slow 20 geochemical cycle" for these materials in the absence of biota. Biota obviously play a major part in the carbon cycle, and Berner (1990) explicitly recognized organic production and respiration as a "rapid cycle" that accompanies the standard Ebelmen-Urey cycle. In fact, Ebelmen and other early researchers discussing the weathering cycle recognized the importance of biota (Berner, 1995; Berner and Maasch, 1996). Representing organic matter as $\mathrm{CH}_{2} \mathrm{O}$, the following reaction describes the synthesis of organic matter from $\mathrm{CO}_{2}$ and water, and its remineralization by respiration:

$\mathrm{CO}_{2}+\mathrm{H}_{2} \mathrm{O}=\mathrm{CH}_{2} \mathrm{O} \downarrow+\mathrm{O}_{2} \uparrow$

Smith and Veeh (1989) pointed out that some shallow-water calcifying ecosystems with long water residence time approach $\mathrm{CO}_{2}$ compensation between $\mathrm{CO}_{2}$ evasion 6585

BGD

$6,6579-6599,2009$

\section{Lithogenic, atmospheric, and biogenic cycles}

S. V. Smith and J.-P. Gattuso

Title Page

Abstract Introduction

Conclusions

Tables

References

Figures

14

$>1$

4

Back

Full Screen / Esc

Printer-friendly Version

Interactive Discussion 
associated with $\mathrm{CaCO}_{3}$ precipitation and $\mathrm{CO}_{2}$ uptake associated with organic carbon production:

$\mathrm{Ca}^{2+}+2 \mathrm{HCO}_{3}^{-} \rightarrow \mathrm{CaCO}_{3} \downarrow+\mathrm{CH}_{2} \mathrm{O} \downarrow+\mathrm{O}_{2} \uparrow$

BGD

6, 6579-6599, 2009

Equations (4) and (7) can be combined in the following manner to include $\psi$ in a re5 action that eliminates gas flux:

$\mathrm{Ca}^{2+}+2 \mathrm{HCO}_{3}^{-} \rightarrow \mathrm{CaCO}_{3} \downarrow+\psi\left(\mathrm{CH}_{2} \mathrm{O} \downarrow+\mathrm{O}_{2} \uparrow\right)+(1-\psi)\left(\mathrm{HCO}_{3}^{-}+\mathrm{H}^{+}\right)$

Thus, a combination of $\mathrm{CaCO}_{3}$ precipitation and organic production in surface waters can maintain $p \mathrm{CO}_{2}$ relatively constant, even though $\mathrm{pH}$ and $\mathrm{TA}$ are depressed. This provides a mechanism by which oceanic $\mathrm{CaCO}_{3}$ and organic $\mathrm{C}$ reactions can cycle carbon internally, with relatively little interaction with the atmosphere.

\section{The aqueous $\mathrm{CO}_{2}$ system in the open ocean}

The central oceanic water column may be considered to be an isolated system analogous to the shallow-water isolated ecosystems that led to the above concept, although with an important difference. The production of reactive organic and inorganic and inor15 ganic particles from dissolved materials in the upper ocean and the sinking and subsequent decomposition of these particles back to dissolved materials at depth effectively divide the oceanic system into two geochemically distinctive but strongly interactive sub-systems. The surface ocean production, sinking, and decomposition of particles links the two sub-systems, while together they remain an isolated total system. Little accumulation of either organic or inorganic sediment occurs in the open ocean at depths $>4000 \mathrm{~m}$ in the North Pacific Gyre, so the only effective exchange of carbon is between the atmosphere and the upper ocean.

Figure 1 presents 20-year average conditions of water composition and $\psi$ for an oceanographic station $100 \mathrm{~km}$ north of Oahu, Hawaii ( 4700 m water depth). A log scale is used for depth, and raw data (in $\mathrm{m}$ ) have been bin-averaged into intervals of 0.1

\section{Lithogenic, atmospheric, and biogenic cycles}

S. V. Smith and J.-P. Gattuso

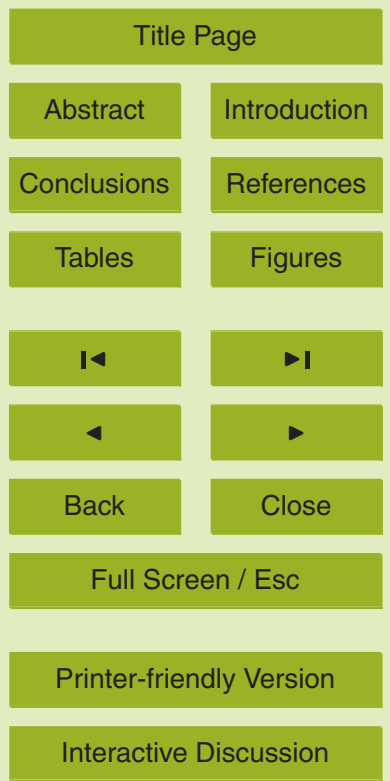


log units in order to highlight both the compositional difference between the upper and lower water column and the composition gradients between the two. For these data, TA and DIC (measured to high precision at the station) were used as the master variables to partition the $\mathrm{CO}_{2}$ system. Calculations include hydrostatic pressure effects on the $5 \mathrm{CO}_{2}$ system. Also included are calculations of $\psi$ and carbonate mineral saturation state $\left(\Omega=\left[\mathrm{Ca}^{2+}\right] *\left[\mathrm{CO}_{3}^{2-}\right] / K_{\mathrm{sp}}^{\prime}\right.$; where [ ] denotes concentration, and $K_{\mathrm{sp}}^{\prime}$ is the mineral solubility product constant) for the two prominent carbonate minerals precipitated by planktonic organisms, low-Mg calcite and aragonite.

Salinity varies vertically. In order to visualize the non-conservative behavior of DIC 10 and TA relative to salinity, both DIC and TA were normalized to a constant salinity of 35 (represented by $\mathrm{DIC}^{*}$ and $\mathrm{TA}^{*}$, respectively). With these normalizations, it is seen that DIC $^{*}$ is constant above $\sim 100 \mathrm{~m}$ (the long-term averages of the base of the euphotic zone and the mixed layer depth approximately coincide at this station), then increases between that depth and about $1000 \mathrm{~m}$. It decreases slightly below $1000 \mathrm{~m}$. TA* is 15 constant to a depth of approximately $300 \mathrm{~m}$ (well below the mixed layer and euphotic zone), increases to a depth of $\sim 1000 \mathrm{~m}$, and then is constant.

Both net organic carbon production and $\mathrm{CaCO}_{3}$ precipitation obviously occur in the upper water column. Therefore, constant, low values for $\mathrm{DIC}^{*}$ and $\mathrm{TA}^{*}$ in the euphotic zone relative to the deep ocean represent the combined effects of uptake of both 20 DIC and TA into $\mathrm{CaCO}_{3}$, uptake of DIC into organic matter, release of $\mathrm{HCO}_{3}^{-}$from calcification-mediated $\mathrm{CO}_{2}$ gas evasion, and mixing of this water to constant composition.

The surface water $p \mathrm{CO}_{2}$ averages about 340 ppmv, about 20 ppmv below atmospheric $p \mathrm{CO}_{2}$ over the duration of the sampling period. For purposes of this analysis, we may consider this to be in approximate equilibrium with the atmosphere. $\mathrm{Net} \mathrm{CaCO}_{3}$ precipitation (represented by constant and low $\mathrm{TA}^{*}$ relative to the deep ocean) persists downward to about $300 \mathrm{~m}$, while both respiration and calcification elevate $\mathrm{DIC}^{*}, p \mathrm{CO}_{2}$, and $\psi$. Rising $\mathrm{DIC}^{*}$ and $\mathrm{TA}^{*}$ between 300 and $900 \mathrm{~m}$ represent the net effect of decomposing organic matter and $\mathrm{CaCO}_{3}$, with no gas exchange with the atmosphere. Organic

\section{BGD}

$6,6579-6599,2009$

\section{Lithogenic, atmospheric, and biogenic cycles}

S. V. Smith and J.-P. Gattuso

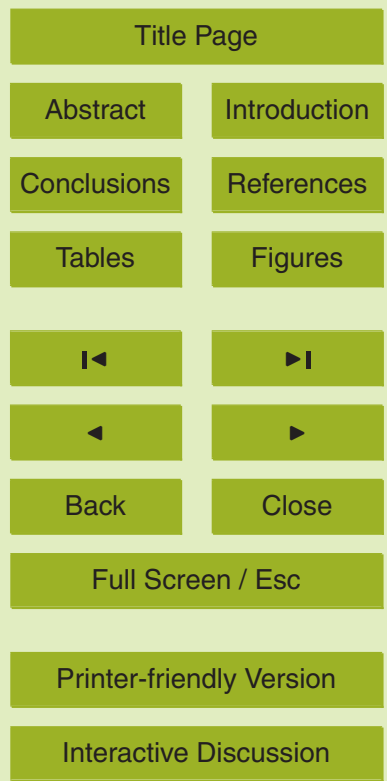


decomposition is complete by $\sim 1000 \mathrm{~m}$, and there is little further downward change in $\Omega$ for either calcite or aragonite. The dramatic $p \mathrm{CO}_{2}$ decrease below $1000 \mathrm{~m}$, a slight continuing rise in TA, and a slight decrease in $\psi$ represent some continuing $\mathrm{CaCO}_{3}$ dissolution in the absence of organic oxidation.

$5 \quad \psi$ and $\Omega$ are constant in the euphotic zone/mixed layer. $\psi$ rises from 0.6 to 0.9 between 100 and $800 \mathrm{~m}$, in response to both oxidation of organic matter and diminished temperature. Below $1000 \mathrm{~m}, \psi$ decreases slightly as $p \mathrm{CO}_{2}$ is lowered by $\mathrm{CaCO}_{3}$ dissolution in the absence of additional organic oxidation products.

$\mathrm{CaCO}_{3}$ dissolution above the lysocline is contrary to long-held beliefs dating back 10 to the Challenger Expedition. However, the trend we observe and our interpretation of it are consistent with the growing body of recent evidence (e.g., Milliman and Droxler, 1996; Milliman et al., 1999; Feely et al., 2002), that most $\mathrm{CaCO}_{3}$ dissolution occurs in water shallower than $1000 \mathrm{~m}$. The lysocline marks the depth above which - rather than below which - most dissolution of $\mathrm{CaCO}_{3}$ occurs. Further, only a small proportion of 15 the water column ( $\sim 3 \%$ of its volume, $2 \%$ of the DIC mass) has $\psi$ constrained by gas exchange between the air and water; about another $15 \%$ is a mixing transition zone; the remainder has $\psi$ slightly below 1.0 .

\section{Scenarios of "no $\mathrm{CaCO}_{3}$ " and "no organic C" reactions in the open ocean}

The data shown in Fig. 1 can be used to develop scenarios for the distribution of $\mathrm{CO}_{2}$ 20 related variables under regimes of no $\mathrm{CaCO}_{3}$ precipitation and dissolution, and no organic $\mathrm{C}$ production and respiration. These scenarios are not intended to be realistic, but rather to explore the geochemical implications of these end member conditions. A scenario in which there are no $C$ reactions is used as a baseline for comparison. For these calculations, observed temperature distribution is used; DIC and TA are again normalized to a salinity of 35 . Further, it is assumed that in the absence of $\mathrm{CaCO}_{3}$ reactions, TA in the oceanic water column would homogenize to the present water column average value of $2420 \mu \mathrm{eq} \mathrm{kg}^{-1}$. Finally, the calculations use contemporary

\section{Lithogenic, atmospheric, and biogenic cycles}

S. V. Smith and J.-P. Gattuso

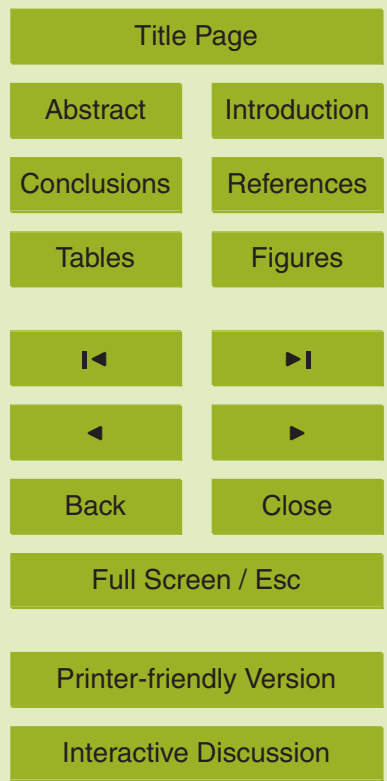


mixed layer $p \mathrm{CO}_{2}$ (i.e., $340 \mathrm{ppmv}$ ).

Numerical integration of Fig. $2 a$ to the bottom of the sampled profile $(4450 \mathrm{~m})$ provides information on the magnitude of the water-column DIC reservoir. Relative reservoir sizes are also scaled to the C-neutral reservoir value of $9500 \mathrm{~mol} \mathrm{~m}^{-2}$ (Table 1).

5 The observed contemporary ocean reservoir is about $13 \%$ above $\mathrm{C}$-neutral. This reflects the results of combined contemporary organic and inorganic $\mathrm{C}$ particle production in the upper water column, downward transport of those particles, and their total decomposition at depth. In the absence of $\mathrm{CaCO}_{3}$ reactions, the reservoir is about $33 \%$ above $\mathrm{C}$-neutral, indicating the strength of the biological $\mathrm{C}$ pump. The reservoir without organic $\mathrm{C}$ reactions is $3 \%$ below $\mathrm{C}$-neutral; that is, $\mathrm{CaCO}_{3}$ reactions are a net source of $\mathrm{CO}_{2}$ release to the atmosphere. The contemporary ocean is only slightly closer to the no- $\mathrm{CaCO}_{3}$ end member than to the no-organic $\mathrm{C}$ end member. Thus the $\mathrm{CaCO}_{3}$ dissolution at depth and with higher values for $\psi$ during dissolution than during surface precipitation apparently is an important component of the net oceanic biogeochemical 15 C pump.

Water column $p \mathrm{CO}_{2}$ in deep water in the absence of $\mathrm{CaCO}_{3}$ reactions would be about 8 times the contemporary value (Fig. 2c), while $p \mathrm{CO}_{2}$ in the deep water would actually diminish below surface ocean values in the absence of organic carbon reactions. Note that the $p \mathrm{CO}_{2}$ scale is logarithmic, so that variations for all three conditions can be visualized on a single graph. One oceanic consequence of the no- $\mathrm{CaCO}_{3}$ scenario would be that any region with outcropping deep water (i.e., upwelling zones) would effectively ventilate $\mathrm{CO}_{2}$ to the atmosphere because of the extremely elevated $p \mathrm{CO}_{2}$.

A useful metric for comparison is that the $\mathrm{C}$ reservoir size for the contemporary 25 atmospheric column above the Earth surface is about $120 \mathrm{~mol} \mathrm{~m}^{-2}$. Thus, the oceanic reservoir variations among these various scenarios are all far larger than the magnitude of the atmospheric reservoirs size.

The results for $\Omega$ (shown only for calcite, the dominant form of planktonic $\mathrm{CaCO}_{3}$ ) are also interesting, particularly with respect to the no- $\mathrm{CaCO}_{3}$ scenario. Water below

BGD

$6,6579-6599,2009$

\section{Lithogenic, atmospheric, and biogenic cycles}

S. V. Smith and J.-P. Gattuso

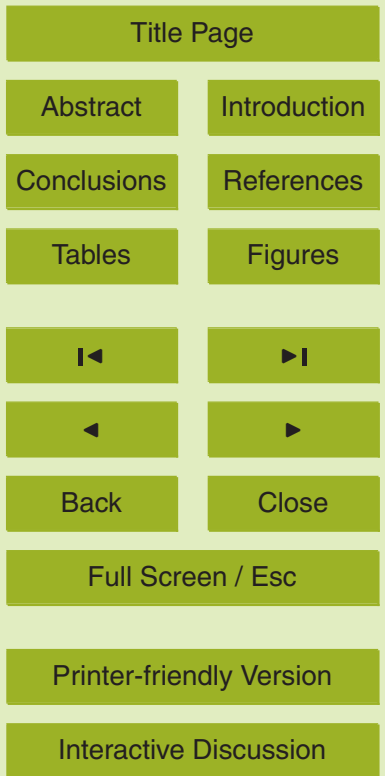


the mixed layer would be very undersaturated $\left(\Omega_{\text {calcite }}<0.5\right.$ by $500 \mathrm{~m}$ and near 0.1 by $1000 \mathrm{~m}$ ). This compares with contemporary $\Omega$ only slightly below 1.0 even at the base of the sampled water column. The highly corrosive water of the no- $\mathrm{CaCO}_{3}$ scenario would tend dissolve any calcareous sediments in contact with the water, acting as

5 a feedback on the other variables. In the no-organic $C$ scenario, $\Omega_{\text {calcite }}$ would remain well above 1.0. In fact, the modeled drop below surface ocean values is, to a great extent, an artifact. The contemporary $\mathrm{CaCO}_{3}$ dissolution above the lysocline is clearly related to biotically mediated dissolution, and this mediation would not occur in the absence of organic $\mathrm{C}$ reactions.

10 Finally, note $\psi$ (Fig. 2e). The upper water column value is quite stable, near 0.6 for all scenarios, to a depth of about $200 \mathrm{~m}$. In the absence of organic metabolism, it remains near 0.6 through the lower water column. In the absence of $\mathrm{CaCO}_{3}$ reaction, it rises to 1.0 throughout in the deep water column (where most of the DIC storage occurs). This reflects the importance of organic reactions (specifically, oxidation, without gas 15 evasion) in elevating $\psi$ to unity. Varying ratios of $\mathrm{CaCO}_{3}$ :organic $\mathrm{C}$ delivery to the deep ocean would both alter $\psi$ and store greater or lesser amounts of DIC in the deep ocean.

\section{Implications with respect to ocean acidification}

With present concerns about ocean acidification resulting from the oceanic uptake of anthropogenic $\mathrm{CO}_{2}$, it is appropriate to consider $\psi$ for surface seawater in response to changing atmospheric and upper ocean $p \mathrm{CO}_{2}$. Brewer and Peltzer (2009) showed that $p \mathrm{CO}_{2}$ could be expected to reach water column values greater than $3500 \mathrm{ppmv}$ in a station of the eastern tropical Pacific, owing to the diminished buffer capacity of the increasingly acidified water both at the sea surface and with increasing water column

oxidation of organic matter. The scenarios presented in Fig. 2 would suggest that $\psi$ should rise and $\Omega$ should fall in response to rising atmospheric $p \mathrm{CO}_{2}$.

There is mounting evidence that acidification is affecting calcification, although it is

BGD

$6,6579-6599,2009$

\section{Lithogenic, atmospheric, and biogenic cycles}

S. V. Smith and J.-P. Gattuso

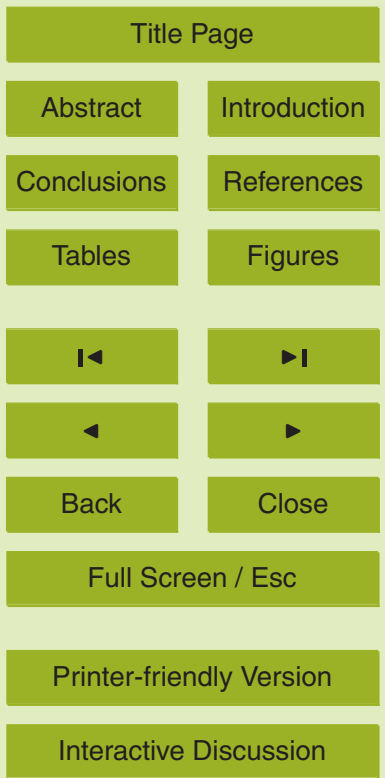


by no means certain that there will be a single general rule to describe this effect. The decline of calcification will have two concomitant and antagonistic impacts on the carbonate chemistry of the surface ocean (Gattuso et al., 1999b). On the one hand, less calcification means less $\mathrm{CO}_{2}$ released to the water column. On the other hand, the 5 increase in $\psi$ will lead to a greater release of $\mathrm{CO}_{2}$ per each mole of $\mathrm{CaCO}_{3}$ precipitated (Eq. 4). The reverse of this effect is propagated downward into the water column, as $\mathrm{CaCO}_{3}$ dissolves.

We make a simple assumption and develop a surface water calcification index $(\mathrm{Cl})$ that scales calcification proportional to $\Omega_{\text {calcite }}$ (Table 2). We use $\mathrm{Cl}$, surface $\mathrm{TA}^{*}$ scaled 10 to $\mathrm{Cl}$, present deep-water $\mathrm{TA}^{*}$, and a constant water-column average $\mathrm{TA}^{*}$ in order to develop profiles for TA* ${ }^{*}$. We assume that release of DIC from OC oxidation does not change from contemporary. With these assumptions, we calculate profiles of DIC* , $p \mathrm{CO}_{2}, \Omega_{\text {calcite }}$, and $\psi$ for surface water at $p \mathrm{CO}_{2}$ values of pre-industrial ( $\left.280 \mathrm{ppmv}\right)$, contemporary ( 380), 2, and 3 times contemporary (Fig. 3). In effect, our treatment extends the calculation made by Brewer and Peltzer (2009) in the Eastern Tropical Pacific to include effects of $\psi$. There is an upward shift of $\psi$ from about 0.57 to 0.77 in the upper ocean over this range of conditions. The combined effect of the two mechanisms described above is towards less $\mathrm{CO}_{2}$ released (Table 2).

The Hawaii station is more oligotrophic than the station analyzed by Brewer and 20 Peltzer (2009). Despite the lower amount of organic C produced and consumed at the Hawaii station, maximum water-column $p \mathrm{CO}_{2}$ values $(2300 \mathrm{ppmv}, 2 \times$ atmospheric $\mathrm{CO}_{2} ; 3300$ ppmv, $3 \times$ ) are very similar to the values reported by those authors. At $2 \times$ atmospheric $p \mathrm{CO}_{2}, \psi$ reaches or exceeds 0.95 throughout the water column below $700 \mathrm{~m}$ at the Hawaii station.

25 The changing size of the oceanic carbon reservoir with increasing $p \mathrm{CO}_{2}$ and decreasing upper water column calcification can be seen in Table 1. It is evident that the net sink strength will diminish as atmospheric $\mathrm{CO}_{2}$ rises and calcification decreases.

Note that this assessment of sink strength in response to ocean acidification is greatly simplified. In particular, physical considerations, temperature, and more com-

BGD

6, 6579-6599, 2009

\section{Lithogenic, atmospheric, and biogenic cycles}

S. V. Smith and J.-P. Gattuso

Title Page

Abstract Introduction

Conclusions

Tables References Figures

14

4

Back

Full Screen / Esc

Printer-friendly Version

Interactive Discussion 
plex relationships between $\mathrm{CaCO}_{3}$ reactions and acidification can be considered (see, for example, Heinze, 2004; Gehlen et al., 2007).

\section{Conclusions}

The introduction of organic carbon reactions into the weathering-precipitation couplet 5 provides a plausible conceptual reconciliation between the Ebelmen-Urey reactions and the quantitative chemical behavior of $\mathrm{CaCO}_{3}$ reactions in seawater. The heretofore problematic coefficient, $\psi$, is a sensitive variable related to $\mathrm{CaCO}_{3}$ and organic matter reactions, DIC storage in the ocean, and $\mathrm{CO}_{2}$ gas exchange between the ocean and atmosphere. Variation in $\psi$ vertically in the water column, with changing atmospheric $10 \mathrm{COO}_{2}$, and in response to changing proportions of $\mathrm{CaCO}_{3}$ and organic $\mathrm{C}$ reactions affect air-sea gas exchange and the oceanic carbon storage reservoir. An important aspect of this coefficient is that relatively subtle variations in the characteristics of both $\mathrm{CaCO}_{3}$ and organic $\mathrm{C}$ reactions in the oceanic water column, acting in concert with $\psi$ can dramatically alter the magnitude of the oceanic storage of $C$ relative to the much smaller size of the atmospheric $\mathrm{C}$ reservoir.

Acknowledgements. We thank several people for their discussions of this problem over many years. We particularly identify the following supportive skeptics who challenged us to find a reconciliation between the " 0.6 rule" and the weathering cycle equations: R. Berner, R. Garrels, F. Mackenzie and R. Wollast. F. Mackenzie, R. Berner, and L. Legendre have all provided gratefully acknowledged, particularly for his recognition of variation in the coefficient $\psi$. This work is a contribution to CARBOOCEAN (FP6/511176-2), and to the "European Project on Ocean Acidification" (EPOCA), which receives funding from the European Community's Seventh Framework Programme under grant agreement 211384.

BGD

6, 6579-6599, 2009

\section{Lithogenic, atmospheric, and biogenic cycles}

S. V. Smith and J.-P. Gattuso

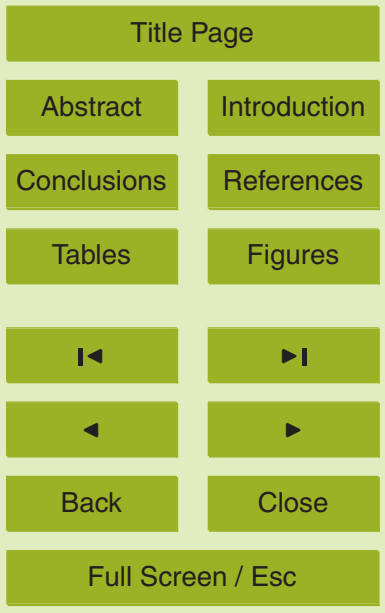

Printer-friendly Version

Interactive Discussion 


\section{References}

Arvidson, R. S., Mackenzie, F. T., and Guidry, M.: MAGic: A Phanerozoic model for the geochemical cycling of major rock-forming components, Am. J. Sci., 306, 135-190, 2006.

Berner, R. A.: Atmospheric carbon dioxide levels over Phanerozoic time, Science, 249, 13821386, 1990.

Berner, R. A.: A. G. Högbom and the development of the concept of the geochemical carbon cycle, Am. J. Sci., 295, 491-495, 1995.

Berner, R. A. and Maasch, K. A.: Chemical weathering and controls on atmospheric $\mathrm{O}_{2}$ and $\mathrm{CO}_{2}$ : Fundamental principles were enunciated by J. J. Ebelmen in 1845, Geochim. Cosmochim. Ac., 60, 1633-1637, 1996.

Brewer, P. G. and Peltzer, E. T.: Limits to marine life, Science, 324, 347-348, 2009.

Dickson, A. G.: An exact definition of total alkalinity and a procedure for the estimation of alkalinity and total inorganic carbon from titration data, Deep-Sea Res. A, 28, 609-623, 1981.

15 Ebelmen, J. J.: Sur les produits de la décomposition des espèces minérales de la famille des silicates, Ann. Mines, 7, 3-66, 1845.

Edmond, J. M.: High precision determination of titration alkalinity and total carbon dioxide content of sea water by potentiometric titration, Deep-Sea Res., 17, 737-750, 1970.

Feely, R. A., Sabine, C. L., Lee, K., Millero, F. J., Lamb, M. F., Greeley, D., Bullister, J. L., Key, R. M., Peng, T.-H., Kozyr, A., Ono, T., and Wong, C. S.: In situ calcium carbonate dissolution in the Pacific Ocean, Global Biogeochem. Cy., 16, doi:10.1029/2002GB001866, 2002.

Frankignoulle, M.: A complete set of buffer factors for acid/base $\mathrm{CO}_{2}$ system in seawater, J. Marine Syst., 5, 111-118, 1994.

Frankignoulle, M., Canon, C., and Gattuso, J.-P.: Marine calcification as a source of carbon dioxide: positive feedback of increasing atmospheric $\mathrm{CO}_{2}$, Limnol. Oceanogr., 39, 458-462, 1994.

Gattuso, J.-P., Frankignoulle, M., and Smith, S. V.: Measurement of community metabolism and significance in the coral reef $\mathrm{CO}_{2}$ source-sink debate, Proc. Nat. Acad. Sci., 96, 1301713022, 1999a.

Gattuso, J.-P., Allemand, D., and Frankignoulle, M.: Photosynthesis and calcification at cellular, organismal and community levels in coral reefs: a review on interactions and control by
BGD

6, 6579-6599, 2009

\section{Lithogenic, atmospheric, and biogenic cycles}

S. V. Smith and J.-P. Gattuso

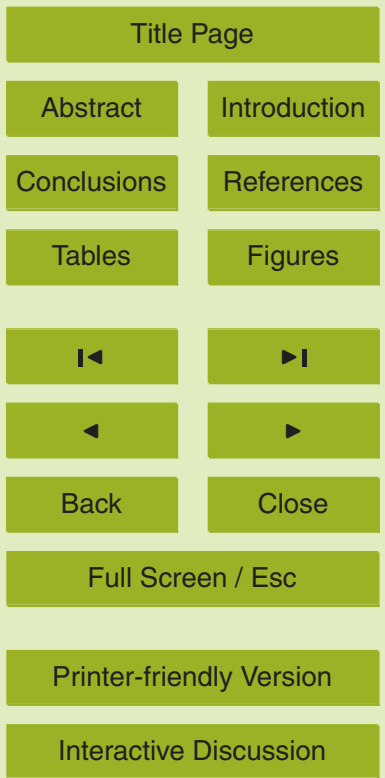


carbonate chemistry, Am. Zool., 39, 160-183, 1999b.

Gehlen M., Gangstø R., Schneider B., Bopp L., Aumont O., and Ethe C.: The fate of pelagic $\mathrm{CaCO}_{3}$ production in a high $\mathrm{CO}_{2}$ ocean: A model study, Biogeosciences, 4, 505-519, 2007, http://www.biogeosciences.net/4/505/2007/.

5 Heinze C.: Simulating oceanic $\mathrm{CaCO}_{3}$ export production in the greenhouse, Geophys. Res. Lett., 31, L16308, doi:10.1029/2004GL020613, 2004.

Lewis, E., and Wallace, D. W. R.: Program developed for $\mathrm{CO}_{2}$ system calculations. ORNL/CDIAC-105, Carbon Dioxide Information Analysis Center, Oak Ridge National Laboratory, U.S. Department of Energy, Oak Ridge, Tennessee, 1998, http://cdiac.esd.ornl.gov/ 10 oceans/co2rprt.html.

Milliman, J. D. and Droxler, A. W.: Neritic and pelagic carbonate sedimentation in the marine environment: ignorance is not bliss, Geol. Rundsch., 85, 496-504, 2006.

Milliman, J. D., Troy, P. J., Balch, W. M., Adams, A. K., Li, Y.-H., and Mackenzie, F. T.: Biologically mediated dissolution of calcium carbonate above the chemical lysocline?, Deep-Sea Res. Pt.

15 I, 46, 1653-1669, 1999.

Park, P. K.: Oceanic $\mathrm{CO}_{2}$ system: An evaluation of ten methods of investigation, Limnol. Oceanogr., 14, 179-186, 1969.

Pierrot, D. E., Lewis, E., and Wallace, D. W. R.: MS Excel program developed for $\mathrm{CO}_{2}$ system calculations. ORNL/CDIAC-105. Carbon Dioxide Information Analysis Center, Oak Ridge National Laboratory, U.S. Department of Energy, Oak Ridge, Tennessee, 2006, http://cdiac. esd.ornl.gov/oceans/co2rprt.html.

Sigman, D. M. and Boyle, E. A.: Glacial/interglacial variations in atmospheric carbon dioxide, Nature, 407, 859-869, 2000.

Smith, S. V.: Physical, chemical and biological characteristics of $\mathrm{CO}_{2}$ gas flux across the airwater interface, Plant, Cell Environ., 8, 387-398, 1985.

Smith, S. V. and Veeh, H. H.: Mass balance of biogeochemically active materials $(C, N, P)$ in a hypersaline gulf, Est. Coast. Shelf S., 29, 195-215, 1989.

Urey, H. C.: The Planets: Their Origin and Development. New Haven, Yale University Press, 242 pp., 1952.

so Ware, J. R., Smith, S. V., and Reaka-Kudla, M. L.: Coral reefs: sources or sinks of atmospheric $\mathrm{CO}_{2}$ ? Coral Reefs, 11, 127-130, 1992.

Wollast, R., Garrels, R. M., and Mackenzie, F. T.: Calcite-seawater reactions in ocean surface waters, Am. J. Sci., 280, 831-848, 1980.

BGD

6, 6579-6599, 2009

\section{Lithogenic, atmospheric, and biogenic cycles}

S. V. Smith and J.-P. Gattuso

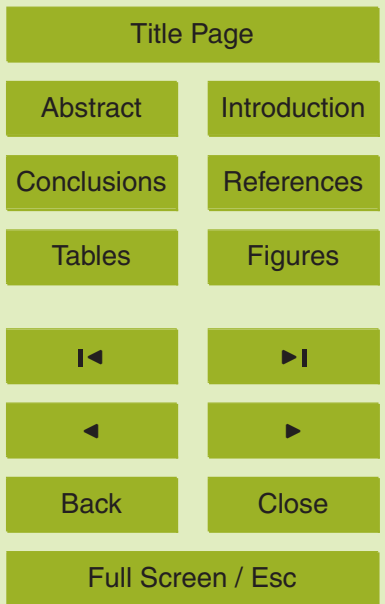

Printer-friendly Version

Interactive Discussion 


\section{BGD}

$6,6579-6599,2009$

Table 1. Water-column reservoir sizes for contemporary (observed) conditions and the 6 scenarios described in Figs. 2 and 3.

\begin{tabular}{lcc}
\hline \multicolumn{3}{c}{ Carbon flux scenarios (340 ppmv) } \\
Scenario & $\mathrm{mol} \mathrm{C} \mathrm{m}^{-2}$ & $\%$ of C-neutral \\
\hline Observed $_{\text {no } \mathrm{CaCO}_{3}}$ & 10700 & 113 \\
no organic C & 12600 & 133 \\
C-neutral & 9200 & 97 \\
& 9500 & - \\
\hline \multicolumn{3}{c}{ Atmospheric $\mathrm{CO}_{2} \mathrm{Scenarios}^{-2}$} \\
Scenario & $\mathrm{mol} \mathrm{C} \mathrm{m}^{-2}$ & $\%$ of observed \\
\hline pre-industrial (280 ppmv) & 10100 & 94 \\
2x pre-industrial (560 ppmv) & 11300 & 105 \\
3x pre-industrial (840 ppmv) & 11500 & 108 \\
\hline
\end{tabular}

\section{Lithogenic, atmospheric, and biogenic cycles}

S. V. Smith and J.-P. Gattuso

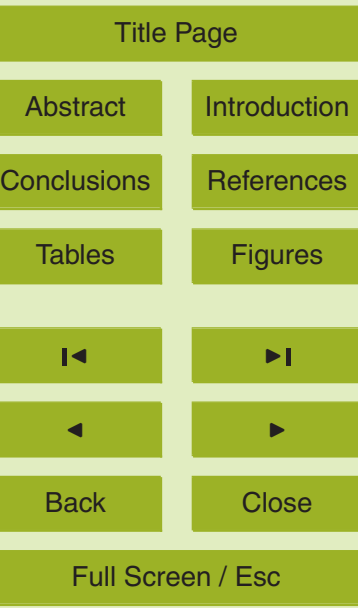

Printer-friendly Version

Interactive Discussion 


\section{BGD}

6, 6579-6599, 2009

\section{Lithogenic, atmospheric, and biogenic cycles}

Table 2. Effect of $p \mathrm{CO}_{2}$ on $\Omega_{\text {calcite }}$ and $\psi$ for surface seawater of $T=25^{\circ} \mathrm{C}, S=35$. Surface $\mathrm{TA}^{*}$ is calculated to match the diminished $\mathrm{Cl}$, based on deviation from water column average $\mathrm{TA}^{*}$. A "calcification index" $(\mathrm{Cl})$ for each scenario $(\mathrm{X})$ is scaled relative to contemporary conditions $(\mathrm{Cl}=1.0)$ and a value of 0 at $\Omega=1.0 . \mathrm{Cl}=\left(\Omega_{X}-1\right) /\left(\Omega_{\text {contemp }}-1\right)$. Relative $\mathrm{CO}_{2}$ flux from calcification in the upper ocean is calculated as $\mathrm{Cl}^{*} \psi$.

\begin{tabular}{lccccc}
\hline$p \mathrm{CO}_{2}$ (ppmv) & $\mathrm{TA}^{*}$ & $\Omega_{\text {calcite }}$ & $\mathrm{Cl}$ & $\psi$ & $\mathrm{CO}_{2}$ flux \\
\hline 280 (pre-industrial) & 2272 & 6.2 & 1.2 & 0.57 & 0.68 \\
340 (contemporary) & 2300 & 5.3 & 1.0 & 0.63 & 0.63 \\
560 (2x pre) & 2342 & 4.2 & 0.7 & 0.70 & 0.49 \\
840 (3x pre) & 2370 & 3.2 & 0.5 & 0.77 & 0.39 \\
\hline
\end{tabular}

S. V. Smith and

J.-P. Gattuso

Title Page

Abstract Introduction

Conclusions References

14

$\rightarrow 1$

4

Back

Close

Full Screen / Esc

Printer-friendly Version

Interactive Discussion 
BGD
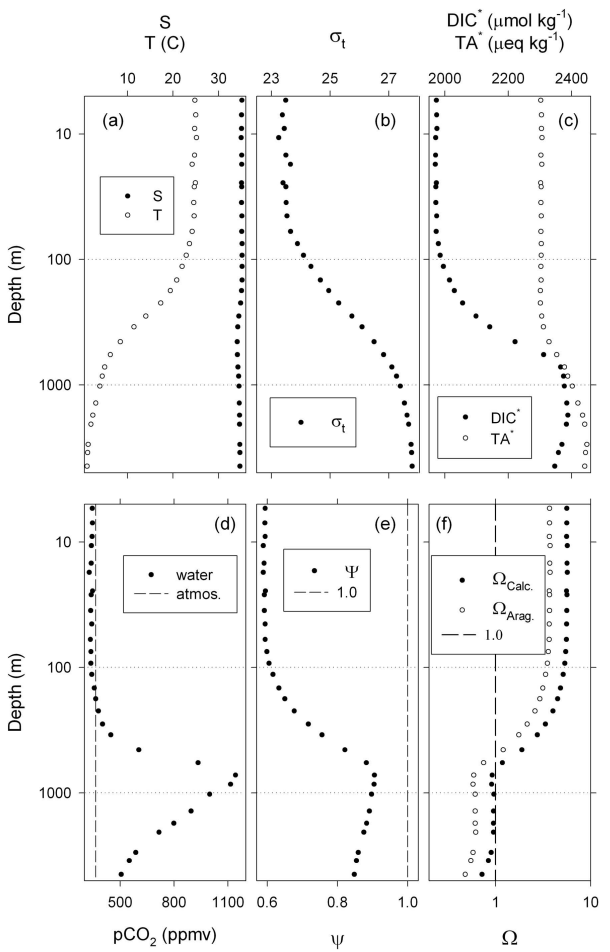

Fig. 1. 1988-2007 average data for temperature, salinity, sigma-t, dissolved inorganic carbon, and TA at Station Aloha $\left(22.75^{\circ} \mathrm{N}, 158.00^{\circ} \mathrm{W}\right)$ and $p \mathrm{CO}_{2}$, from which we calculate $\psi$ and $\Omega$ for calcite and aragonite calculated from these data. $\mathrm{DIC}^{*}$ and $\mathrm{TA}^{*}$ are normalized to $S=35$, to remove conservative effects. Data online at http://hahana.soest.hawaii.edu/hot/hot-dogs/ interface.html.
$6,6579-6599,2009$

\section{Lithogenic, atmospheric, and biogenic cycles}

S. V. Smith and J.-P. Gattuso

Title Page

\section{Abstract}

Conclusions

Tables

14

Back
Introduction

References

Figures

$\rightarrow 1$

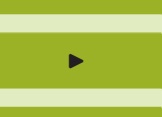

Close

\section{Full Screen / Esc}

Printer-friendly Version

Interactive Discussion 


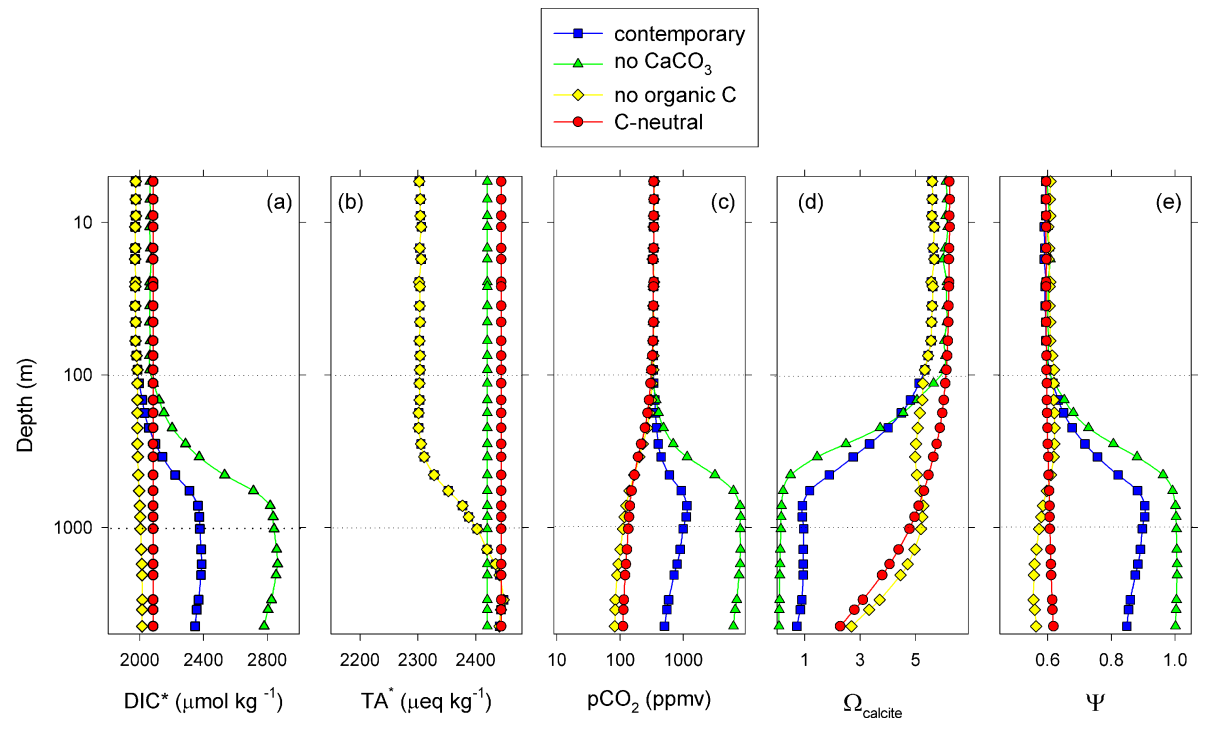

Fig. 2. Water column composition according to the three scenarios of oceanic carbon reactions discussed in the text. These scenarios are derived from the data used in Fig. 1, as discussed in the text. All calculations are based on $\mathrm{DIC}^{*}$ and $\mathrm{TA}^{*}$ (data normalized to $S=35$ ).

\section{Lithogenic, atmospheric, and biogenic cycles}

S. V. Smith and J.-P. Gattuso

Title Page

\section{Abstract}

Conclusions

Tables

14

Back
Introduction

References

Figures

$\rightarrow 1$

$>$

\section{Full Screen / Esc}

Printer-friendly Version 
BGD

$6,6579-6599,2009$

\section{Lithogenic,} atmospheric, and biogenic cycles

S. V. Smith and J.-P. Gattuso

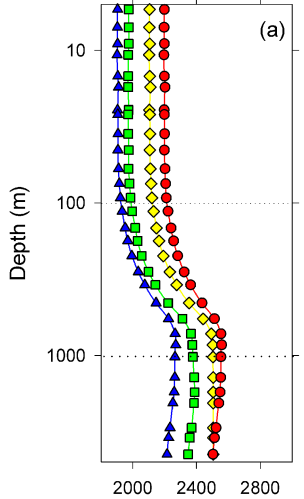

$\mathrm{DIC}^{*}\left(\mu \mathrm{mol} \mathrm{kg}^{-1}\right)$
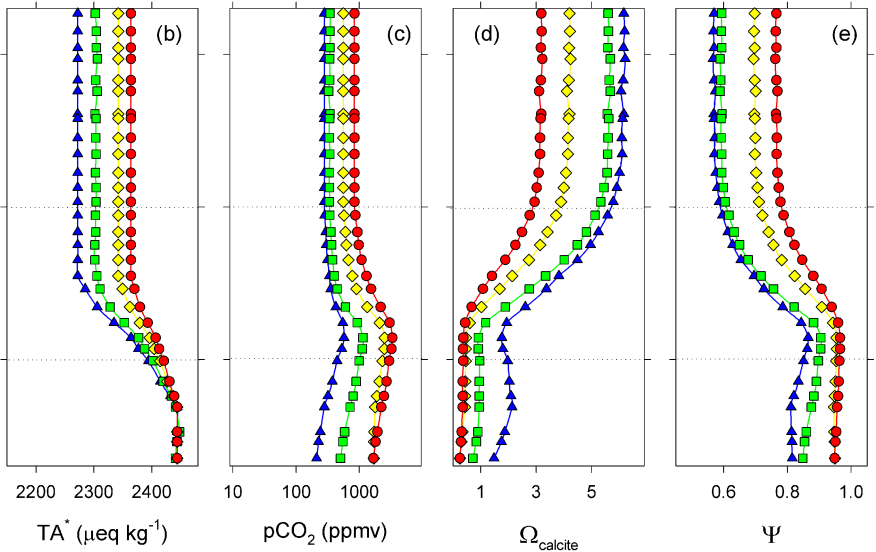

Fig. 3. Observed water column composition according to the three scenarios of elevated atmospheric $\mathrm{CO}_{2}$ discussed in the text. These scenarios are derived from the data used in Fig. 1. All calculations are based on $\mathrm{DIC}^{*}$ and $\mathrm{TA}^{*}$ (data normalized to $\mathrm{S}=35$ ).

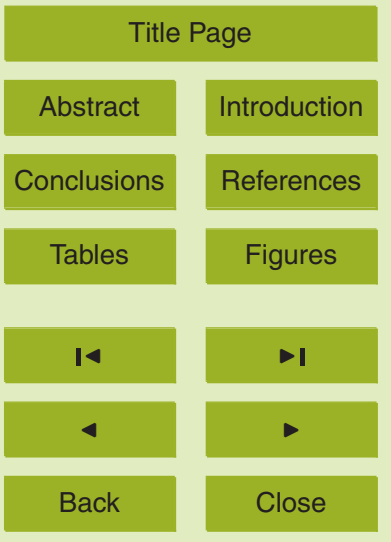

Full Screen / Esc

Printer-friendly Version 